\title{
PENGARUH MOTIVASI DAN KOMITMEN TERHADAP EFEKTIVITAS KERJA GURU SD NEGERI KECAMATAN CABANGBUNGIN KABUPATEN BEKASI
}

\author{
Andri Cahyo Purnomo ${ }^{l}$ \\ Deden Kurnia ${ }^{2}$ \\ Andre Ramadhan ${ }^{3}$ \\ Dosen STMIK Raharja ${ }^{1}$, STMIK Raharja Jurusan Sistem Informasi ${ }^{2,3}$ \\ Jl. Jendral Sudirman No. 40, Modern Cikokol, Tangerang ${ }^{1,2,3}$ \\ Email : andricahyo@raharja.info ${ }^{1)}$, dedenkurnia@raharja.info ${ }^{2}$, andre.ramadhan@raharja.info ${ }^{3)}$
}

\begin{abstract}
ABSTRAK
Penelitian ini bertujuan untuk mengetahui dan memperoleh data empiris mengenai pengaruh (1) motivasi, (2) komitmen, (3) efektivitas kerja guru Sekolah Dasar Negeri Kecamatan Cabangbungin Kabupaten Bekasi dari bulan Maret sampai dengan Mei 2015. Guru diharapkan memahami apa itu motivasi, serta meningkatkan komitmen dalam bekerja, dan menciptakan efektivitas kerja. Kepala Sekolah pada SD Negeri Kecamatan Cabangbungin, diharapkan membantu para guru agar memiliki motivasi tinggi dalam bekerja, meningkatkan komitmen, serta menciptakan efektivitas kerja. Metode penelitian yang digunakan adalah penelitian kuantitatif, dengan menggunakan Teknik analisis data. Penelitian ini juga menggunakan metode survey kausal dengan menggunakan jalur teknik analisis. Penelitian ini menggunakan sampel dari 97 guru di 12 Sekolah Dasar Negeri di Kecamatan Cabangbungin Kabupaten Bekasi yang dipilih dengan menggunakan rumus Slovin. Hasil penelitian menunjukkan bahwa: pertama, ada pengaruh positif antara motivasi dan efektivitas kerja guru di sekolah, hal ini dapat ditunjukkan dengan semakin tinggi motivasi maka akan semakin baik efektivitas kerja guru SD Negeri Kecamatan Cabangbungin Kabupaten Bekasi. Kedua, ada efek positif antara komitmen dan efektivitas kerja guru di sekolah. Hal ini dapat ditunjukkan dengan semakin tinggi komitmen maka akan semakin baik efektivitas kerja guru SD Negeri Kecamatan Cabangbungin Kabupaten Bekasi. Dari hasil penelitian didapatkan bahwa variabel yang paling berpengaruh adalah komitmen terhadap efektivitas kerja, hal ini dapat dibuktikan dari hasil perhitungan statistik dengan nilai $r_{23}=0,459, p_{32}=0,352$ paling tinggi dibandingkan pengaruh antar variabel lainnya. Ketiga, ada efek positif antara motivasi dan komitmen guru di sekolah. Hal ini menunjukkan bahwa motivasi yang tinggi akan meningkatkan komitmen, pengakuan atas kerja guru dan pemberian apresiasi atas hasil kerja guru. Tindak lanjut dari penelitian ini guru diharapkan memiliki komitmen yang tinggi dalam menjalankan pekerjaannya dengan rasa cinta, niat yang baik untuk ibadah sehingga dapat bekerja dengan maksimal di dalam setiap tugas tanpa mengutamakan imbalan bekerja setulus hati, memberikan pelayanan pendidikan yang berkualitas kepada peserta didik demi mewujudkan kemajuan pendidikan di Indonesia.
\end{abstract}

Kata kunci: motivasi, komitmen dan efektivitas kerja

\begin{abstract}
This study aims to find and obtain empirical data on the influence (1) motivation, (2) commitment, (3) the effectiveness of teachers of the elementary school of the Branch District of Cabangbungin Bekasi from March to May 2015. Teachers are expected to understand what is motivation, increase commitment to work, and create work effectiveness. Headmaster at SD Negeri Branch Cabangbungin, is expected to help teachers to have high motivation in work, increase commitment, and create work effectiveness. The research method used is quantitative research, using data analysis techniques. This study also uses a causal survey method using an analytical technique. This study used a sample of 97 teachers in 12 State Elementary Schools in Branch District of Cabangbungin selected by using Slovin formula. The results showed that: first, there is a positive influence between the motivation and
\end{abstract}


effectiveness of teachers in school work, this can be demonstrated by the higher the motivation, the better the effectiveness of teachers working at the State Elementary School Branch Cabangbungin District Bekasi. Secondly, there is a positive effect between commitment and effectiveness of teacher work in school. This can be demonstrated by the higher commitment, the better the effectiveness of teachers working at SD Negeri Banggasi Sub-District Cabangbungin. From the results of the study found that the most influential variable is the commitment to the effectiveness of work, this can be proven from the results of statistical calculations with the value of $r 23=0.459, p 32=0.352$ highest compared to the influence of other variables. Third, there is a positive effect between teacher motivation and commitment in school. This suggests that high motivation will increase commitment, recognition of teacher work and appreciation of teachers' work. Follow-up of this research teachers are expected to have a high commitment in carrying out their work with a sense of love, good intentions for worship so as to work maximally in every task without prioritizing the rewards of working wholeheartedly, providing quality educational services to learners for the sake of progress education in Indonesia.

Keywords: motivation, commitment and work effectiveness

\section{PENDAHULUAN}

Kemerdekaan yang sudah diraih dengan pengorbanan jiwa dan raga oleh para pejuang bangsa, tidak akan berarti jika kemerdekaan itu tidak diisi dengan pembangunan, bangsa Indonesia ingin merdeka karena bangsa ini sudah tidak tahan hidup menderita di bawah penjajahan, dari kemerdekaan itu bangsa Indonesia mencita-citakan masyarakat yang adil dan makmur, semua itu tentu tidak akan terwujud jika kita tidak memiliki sumber daya manusia (SDM) yang memadai dan sumber daya manusia (SDM) hanya dapat dicapai melalui pendidikan.

Pembangunan bidang pendidikan juga memerlukan SDM yang memadai. Sekolah sebagai satu institusi yang membangun pendidikan membutuhkan SDM yang memadai agar tujuan pendidikan dapat diwujudkan, tanpa pendidikan suatu bangsa akan terbelakang, tanpa pendidikan bangsa kita tidak akan mampu menguasai ilmu pengetahuan dan teknologi (IPTEK), IPTEK sarana pokok untuk mendukung pembangunan semesta yang meliputi bidang ideologi, politik, ekonomi, sosial budaya, hukum, kesehatan maupun bidang lainya.

Ketidakefektifan kerja guru dapat dilihat dari pelaksanaan tugas yang setengah hati, bersikap malas-malasan, datang tidak tepat waktu, dan kurang inisiatif dalam pembelajaran. Ketidakefektifan kerja itu masih banyak dijumpai di sekolah-sekolah di Indonesia umumnya, hal tersebut secara empiris sejalan dengan berita dari Media Sorot, (diakses di http://www.mediasorot.com/?p=1378 pada 20 November 2014), disebutkan bahwa tidak maksimalnya efektivitas kerja guru salah satunya disebabkan masih minimnya sarana dan prasarana sekolah, seorang guru harus mengajar dengan kapasitas 40-45 siswa dalam satu ruang kelas, ditambah lagi waktu kegiatan mengajar harus dibuat 2 sampai 3 shift, sehingga guru yang mengajar terlihat kerepotan ${ }^{1}$.

Beberapa fakta yang dipaparkan di atas mengindikasikan bahwa efektivitas kerja masih rendah. secara administrasi para guru mampu, namun secara implementasi guru kurang menguasainya. Belum optimalnya para guru bekerja sesuai dengan prosedur yang ditetapkan, keterbatasan dan kurang terampilnya para guru dalam menggunakkan alat-alat kerja, media pembelajaran, belum adanya komunikasi yang terbuka dengan pimpinan dan rekan kerja, serta belum optimalnya pencapaian tujuan kerja yang diupayakan oleh para guru. Dari beberapa faktor yang mempengaruhi efektivitas kerja guru, dibatasi hanya pada pengaruh motivasi dan 
komitmen terhadap efektivitas kerja guru SD Negeri Kecamatan Cabangbungin Kabupaten Bekasi.

\section{PERUMUSAN MASALAH}

Berdasarkan permasalahan yang diungkapkan pada latar belakang masalah, identifikasi masalah dan pembatasan masalah, maka dapat dirumuskan permasalahan sebagai berikut:

1. Apakah motivasi berpengaruh langsung terhadap efektivitas kerja?

2. Apakah komitmen berpengaruh langsung terhadap efektivitas kerja?

3. Apakah motivasi berpengaruh langsung terhadap komitmen?

\section{KAJIAN TEORETIK}

\section{Efektivitas kerja}

Menurut Gereth R. Jones (2012:6), ${ }^{[2]}$ mengemukakan bahwa, "effectiveness is a measure of the appropriateness of the goals that manager have selected for the organisation to persue, and of the degree to which the organization achieves those goals". Efektivitas adalah ukuran kesesuaian untuk mencapai tujuan organisasi dan sejauh mana organisasi itu mencapai tujuantujuan yang diharapkan dengan efektif. Sementara itu Wegner dan Hollenbeck (2010:261), ${ }^{[3]}$ mengatakan bahwa, "effectiveness is a measure of whether a company is producing what it should produce in light of the goals, objectives, and constituency demands that influence its performance and justify its existence". Efektivitas adalah ukuran apakah institusi memproduksi dan menghasilkan sumber daya untuk mencapai tujuan, tuntutan tujuan, dan lembaga yang mempengaruhi kinerja dan membenarkan keberadaannya. Selanjutnya, menurut Stephen P. Robbins dan Mary Coulter (2012:8), ${ }^{[4]}$ "effectiveness is often described as "doing the right things" that is, doing those work activities that with help the organization reach its the goals". Efektivitas sering digambarkan sebagai "melakukan hal yang benar" yaitu, melakukan kegiatan-kegiatan kerja itu dengan membantu organisasi mencapai tujuantujuannya.

Menurut Mullins (2010:475), ${ }^{[5]}$ "effectiveness is concerned with doing the right things and related the output of the job and what the manager actually achieves". Efektivitas adalah konsep yang berkaitan dengan mengerjakan sesuatu dengan benar dan berhubungan dengan hasil dari pekerjaan serta proses yang dilakukan. Lebih lanjut Mullins mengatakan bahwa efektivitas harus memiliki hubungan dengan kesuksesan yang diterima dalam mencakup berbagai tujuan yang ada pada kinerja dari proses manajemen dan pekerjaan yang sudah ditetapkan dapat tercapai hasil secara nyata. Ronald R. Sims (2011:185), ${ }^{[6]}$ merumuskan efektivitas kerja sebagai berikut, "work effectively is no easy task, and success is not automatic. Rether, must be cared and maintened carefully for them to accomplish their missions." Membuat pekerjaan secara efektif bukanlah tugas yang mudah, dan kunci keberhasilan tidak otomatis bisa tercapai dengan mudah. Sebaliknya, harus dirawat dan dipelihara dengan hati-hati bagi mereka untuk mencapai misi mereka. Selanjutnya Sperry (2011:4), ${ }^{[7]}$ menyatakan "effectiveness means balancing personal development of self and employees with productivity". Keefektifan atau efektivitas dinyatakan sebagai keseimbangan pengembangan personal dengan produktivitas kerja, baik dirinya sendiri maupun pegawai lainnya. Hal tersebut berarti bahwa keefektifan selalu berkaitan antara pengembangan individu di dalam organisasi dengan hasil kerja yang dicapai.

John B. Minner (2010:79), " ${ }^{[8]}$ dalam bukunya mengatakan bahwa, "high work effectiveness is another matter, however, it includes the quality of output for certain, and it 
may include the quantity as well (but not always). It does not include how absenteeism and low turnover, although both have been considered likely outcomes of enrichment in the past (but no longer)'”. Efektivitas kerja yang tinggi adalah bentuk lain, mencakup kualitas output secara pasti, dan dapat mencakup kuantitas (tetapi tidak selalu). Efektivitas kerja yang tinggi tidak termasuk absensi yang rendah dan omset yang rendah, meskipun keduanya telah dianggap kemungkinan hasil pengayaan pekerjaan sebelumnya. Pendapat William dan Keith Davis (2013:7), ${ }^{[9]}$ mengatakan, "effective work means producing the right goods or society deems appropriate, there means do more than just the right thing, it must also perform it activities in the right way. Mean while efficiency work means that it must use the minimum amount of resources needed to produce goods services. For example people business can do better job of shedulling its factories and shipment, the company can serve more customers while using fewer resources." Efektivitas kerja adalah memproduksi barang dan jasa dengan tepat, dengan menggunakan bahan yang tepat dan cara yang tepat pula. Sedangkan efisiensi kerja adalah bekerja dengan menggunakan sehemat mungkin sumber daya yang dibutuhkan untuk menghasilkan barang dan jasa. Sementara pendapat Champoux (2011:199), ${ }^{[10]}$ mengatakan bahwa, "work effectiveness is the behavioral outcome most closely associated with internal motivation internal work motivation is a feeling of self-reward from doing job it self"'. Pernyataan tersebut adalah sebagai berikut, efektivitas kerja adalah hasil perilaku yang paling erat terkait dengan motivasi kerja internal. Motivasi kerja internal adalah perasaan puas atas penghargaan yang diberikan dari melakukan pekerjaan itu sendiri.

Berdasarkan uraian di atas, dapat disintesiskan bahwa efektivitas kerja adalah suatu proses penyelesaian pekerjaan secara tepat dan efisien, dengan indikator: (1) pencapaian target, (2) realisasi tujuan, (3) kualitas pekerjaan, (4) efisiensi pekerjaan, (5) tingkat produktivitas.

\section{Motivasi}

Menurut L. Gibson, Ivancevich, Donelly dan R. Konopaske (2012:126), ${ }^{[11]}$ berpendapat bahwa, "motivation is the concept that describe the forces acting on employee that initiate and direct behavior." Motivasi adalah alat pendorong yang menyebabkan seseorang merasa terpanggil dengan senang hati untuk melakukan suatu kegiatan. Selanjutnya menurut Schermerhorn (2012:102), ${ }^{[12]}$ motivasi diartikan sebagai, "forces within the individual that account for the direction, level, and persistence of a person's effort expended at work." Motivasi merupakan kekuatan dalam diri individu yang menjelaskan, arah, tingkat, dan ketekunan usaha seseorang diterapkan di tempat dia bekerja. Sedangkan menurut Mc.Shane, dan Mary Ann Von Glinow (2010:132), ${ }^{[13]}$ mengemukakan bahwa, "motivation refers to the forces within a person that effect the direction, intensity, and persistence of voluntary behavior." Motivasi merupakan suatu kekuatan dari dalam diri yang akan menimbulkan efek, mengarahkan, intensitas, dan ketekunan kepada perilaku individu. Sedangkan menurut Colquitt (2015:168), ${ }^{[14]}$ "motivation as a set of energetic force that originates both within and outside an employee, initiates, work related effort and determines is direction intensity and persistence". Motivasi merupakan kumpulan kekuatan dari dalam dan dari luar pegawai, memulai pekerjaan yang berhubungan dengan upaya menentukan arah, intensitas secara terus menerus.

Stephen P. Robbins (2011:238), ${ }^{[15]}$ mengatakan bahwa, "motivation as the processes that account for an individuals intensity, direction and persistence of effort coward attaining a goal." Motivasi adalah proses yang mempengaruhi arah, ketekunan yang dilakukan seseorang untuk mencapai tujuan. 
Berdasarkan uraian di atas, dapat disintesiskan bahwa motivasi adalah kekuatan pendorong dari dalam diri seseorang untuk melakukan pekerjaan agar mencapai tujuan yang diinginkan, dengan indikator: (1) semangat kerja, (2) berupaya disiplin, (3) keinginan untuk lebih berkreativitas, (4) keinginan untuk mencapai target kerja, (5) keinginan meningkatkan kompetensi.

\section{Komitmen}

Menurut Bobbi Deporter (2010:299-300), ${ }^{[16] ~ " k o m i t m e n ~ a d a l a h ~ t e k a d ~ y a n g ~ k u a t, ~ y a n g ~}$ mendorong untuk mewujudkannya terlepas dari beberapa rintangan yang mungkin dihadapi”. Selanjutnya Walker (1992:87) mendefinisikan "commitment is the willingness of people to stay with the organization and contribute significantly to achievement of share objective". Komitmen adalah kesediaan orang untuk tinggal dengan organisasi dan berkontribusi penting untuk pencapaian tujuan berbagi. Pengertian lain mengenai komitmen, salah satunya menurut James Gibson, Donelly (2012:182), ${ }^{[17]}$ yaitu, "commitment a sense of identification, loyality, and involvement expressed by and employee toward the organization or unit of the organization". Komitmen menurut pendapat tersebut adalah keikutsertaan atau keterlibatan karyawan/guru didalam suatu organisasi dengan keinginan yang kuat (loyalitas). Sedangkan menurut Robert V. Kail (2013:386), ${ }^{[18]}$ "commitment the willingness to stay with a person though good and bad times." Komitmen merupakan kesediaan untuk tinggal dengan orang dimanapun meskipun dalam keadaan baik atau buruk.

Gary Yukl (2010:299), ${ }^{[19]}$ menyatakan bahwa "commitment is a more likely outcome of a change initiative when people trust their leaders and believe that the change is necessary and likely to be effective (strong referent and expert power)." Komitmen merupakan inisiatif dari dalam diri masing-masing individu untuk berubah kearah yang lebih baik, seperti ketika seseorang mempercayai pemimpinnya maka akan ada perubahan yang diperlukan dan mungkin efektif, ini yang diperlukan oleh seorang pemimpin yang sedang berkuasa yang kuat tidak harus menindas akan tetapi mengayomi bawahannya. Menurut Don Hellriegel, John W. Slocum, Jr (2011:91), [20]“organizational commitment is the strenght of an employee's involvement in the organization and identification with it". Komitmen organisasi adalah kekuatan keterlibatan karyawan dalam organisasi dan pengidentifikasian dengannya.

Berdasarkan uraian di atas, dapat disintesiskan bahwa komitmen adalah kesediaan untuk terlibat aktif di organisasi, keinginan untuk memberikan kontribusi keberhasilan organisasi, keinginan untuk menyesuaikan dengan tujuan dan visi organisasi, keinginan untuk tetap bekerja di organisasi, keinginan bertanggung jawab pada organisasi serta melakukan perubahan kearah yang lebih baik, dengan indikator: (1) loyalitas kerja, (2) bertanggungjawab, (3) patuh aturan, (4) dapat mengidentifikasi tujuan, (5) keterlibatan dalam pekerjaan.

\section{METODOLOGI}

Penelitian ini bertujuan untuk menguji pengaruh langsung; (1) motivasi terhadap efektivitas kerja, (2) komitmen terhadap efektivitas kerja, dan (3) motivasi terhadap komitmen. Penelitian menggunakan metode survey dengan pendekatan teknik analisis jalur. Penelitian dilaksanakan di SD Negeri Kecamatan Cabangbungin Kabupaten Bekasi. Populasi terjangkau penelitian ini sejumlah 128 guru. Sampel penelitian sebayak 97 orang.

Analisa data untuk pengujian hipotesis akan dilakukan dengan menggunakan teknik analisis jalur, yaitu teknik yang diterapkan untuk menjelaskan pengaruh antara variabel- 
variabel penelitian. Sebelum dilaksanakan analisis jalur, uji signifikan regresi dan uji linearitas regresi sebagai prasyarat uji statistik dilakukan pengujian penormalan data dari masing-masing variabel penelitian dengan Uji-Liliefors, Statistik inferensial digunakan untuk menguji hipotesis tentang pengaruh antar variabel dengan menggunakan teknik analisis jalur.

\section{HASIL PENELITIAN YANG RELEVAN}

Beberapa penelitian yang relevan dengan penelitian ini adalah sebagai berikut:

1. Penelitian yang dilakukan oleh Donna Howle, R.N., B.S.N yang berjudul "The Relationship Between The Work Effectiveness Of Staff Nurses And Their Preception Of Their Nurse Managers' Empowerment". [21] Penelitian ini dilakukan penulis untuk menjelaskan mengenai skala kondisi efektivitas kerja, skala kegiatan kerja, dan skala hubungan organisasi adalah komitmen yang digunakan untuk menilai peluang , kekuasaan formal, dan komposisi sosial di tempat kerja.

2. Penelitian yang dilakukan oleh Supattra Kanchanopast, yang berjudul "Working Motivation Factors Affecting Job Performance Effectiveness". "22] Penelitian ini dilakukan penulis untuk menjelaskan mengenai motivasi di tempat kerja untuk Internal Audit Staf dari Kepala Kantor Krung Thai Umum Perusahaan Terbatas sangat penting untuk mendorong seluruh guru untuk dapat bekerja dan cinta organisasi mereka, serta mencapai tujuan efektivitas kerja mereka. Hasil dari penelitian ini akan digunakan untuk mendapatkan keuntungan guru dengan baik melengkapi mereka untuk mempertahankan yang sama tingkat keterampilan dalam organisasi lain.

3. Penelitian yang dilakukan oleh Seung-Bum Yang, Mary E. Guy, yang berjudul "The Effectiveness of Self-Managed Work Teams in Government Organizations". "23] Penelitian ini dilakukan penulis untuk menjelaskan mengenai perbedaan dengan efek langsung terhadap efektivitas kerja, tim kerja swakelola juga dapat memiliki efek tidak langsung. Semakin baik sumber daya organisasi, tingkat kerja sama tim secara positif.

\section{HASIL DAN PEMBAHASAN}

Berdasarkan tinjauan pustaka yang telah dibahas dan kajian empiris di atas, berikut dibahas hasil penelitian sebagai upaya untuk melakukan sintesis antara kajian teori dengan temuan empiris. Adapun secara rinci pembahasan hasil analisis dan pengujian hipotesis penelitian diuraikan sebagai berikut:

\section{Uji Signifikansi dan Linearitas Persamaan Regresi Efektivitas Kerja atas Motivasi}

Dari data hasil perhitungan untuk penyusunan model persamaan regresi antara efektivitas kerja dengan motivasi pada lampiran 5 diperoleh konstanta regresi a $=63,01$ dan koefisien regresi $b=0,50$. Dengan demikian hubungan model persamaan regresi sederhana adalah $\hat{\mathrm{X}}_{3}=63,01+0,50 \mathrm{X}_{1}$. Sebelum model persamaan regresi tersebut dianalisis lebih lanjut dan digunakan dalam menarik kesimpulan, terlebih dahulu dilakukan uji signifikansi dan linearitas persamaan regresi. Hasil perhitungan uji signifikansi dan linearitas disusun pada tabel ANAVA seperti pada tabel di bawah ini: 
Tabel ANAVA Untuk Uji Signifikansi dan Linearitas Persamaan Regresi $\hat{\mathbf{X}}_{3}=\mathbf{6 3 , 0 1}+\mathbf{0 , 5 0 \mathrm { X } _ { 1 }}$

\begin{tabular}{|c|c|c|c|c|c|c|}
\hline \multirow[b]{2}{*}{ Sumber Varians } & \multirow[b]{2}{*}{ dk } & \multirow{2}{*}{$\begin{array}{c}\text { Jumlah } \\
\text { Kuadrat (JK) }\end{array}$} & \multirow{2}{*}{$\begin{array}{c}\text { Rata-rata } \\
\text { Jumlah Kuadrat } \\
\text { (RJK) }\end{array}$} & \multirow[b]{2}{*}{$\mathbf{F}_{\text {hitung }}$} & \multicolumn{2}{|c|}{$\mathbf{F}_{\text {tabel }}$} \\
\hline & & & & & $\alpha=\mathbf{0 , 0 5}$ & $\alpha=\mathbf{0 , 0 1}$ \\
\hline Total & 97 & 1718151 & & & & \\
\hline Regresi a & 1 & 1715301,04 & & & & \\
\hline Regresi b/a & 1 & 588,01 & 588,01 & $\begin{array}{c}24,70 \\
* *\end{array}$ & 3,94 & 6,91 \\
\hline Residu & 95 & 2261,95 & 23,81 & & & \\
\hline $\begin{array}{l}\text { Tuna Cocok } \\
\text { Galat }\end{array}$ & $\begin{array}{l}20 \\
75\end{array}$ & $\begin{array}{c}351,73 \\
1910,22\end{array}$ & $\begin{array}{l}17,59 \\
25,47\end{array}$ & $0,69^{\mathrm{ns}}$ & 1,71 & 2,13 \\
\hline
\end{tabular}

$\begin{array}{cl}\underset{* *}{\text { Keterangan : }} & \\ \mathrm{ns} & \text { : Regresi sangat signifikan }(24,70>6,91 \text { pada } \alpha=0,01) \\ \mathrm{dk} & \text { : Regresi berbentuk linear }(0,69<1,71 \text { pada } \alpha=0,05) \\ \mathrm{JK} & \text { : Jumlah kuadrat } \\ \mathrm{RJK} & \text { : Rata-rata jumlah kuadrat }\end{array}$

Persamaan regresi $\hat{X}_{3}=63,01+0,50 X_{1}$, untuk uji signifikansi diperoleh $F_{\text {hitung }} 24,70$ lebih besar dari pada $F_{\text {tabel }(0,01 ; 1: 95)} 6,91$ pada $\alpha=0,01$. Karena $F_{\text {hitung }}>F_{\text {tabel }}$ maka persamaan regresi dinyatakan sangat signifikan. Untuk uji linearitas diperoleh $F_{\text {hitung }}$ sebesar 0,69 lebih kecil dari pada $F_{\text {tabel }(0,05 ; 20: 75)}$ sebesar 1,71 pada $\alpha=0,05$. Karena $F_{\text {hitung }}<F_{\text {tabel }}$ maka sebaran titik yang terestimasi membentuk garis linear dapat diterima. Secara visual dapat dilihat pada gambar 4.4.



Gambar Grafik Persamaan Regresi $\hat{\mathbf{X}}_{3}=63,01+0,50 X_{1}$

\section{Uji Signifikansi dan Linearitas Persamaan Regresi Efektivitas Kerja atas Komitmen}

Dari data hasil perhitungan untuk penyusunan model persamaan regresi antara efektivitas kerja dengan komitmen pada lampiran 5, diperoleh konstanta regresi $a=61,43$ dan koefisien regresi $b=0,49$. Dengan demikian hubungan model persamaan regresi sederhana adalah $\hat{X}_{3}=61,43+0,49 X_{2}$. Sebelum model persamaan regresi tersebut dianalisis lebih lanjut dan digunakan dalam menarik kesimpulan, terlebih dahulu dilakukan uji signifikansi dan linearitas persamaan regresi. Hasil perhitungan uji signifikansi dan linearitas disusun pada tabel ANAVA seperti pada tabel 4.6. 
Tabel ANAVA Untuk Uji Signifikansi dan Linearitas Persamaan Regresi $\hat{X}_{3}=61,43+0,49 X_{2}$

\begin{tabular}{|c|c|c|c|c|c|c|}
\hline \multirow[b]{2}{*}{$\begin{array}{l}\text { Sumber } \\
\text { Varians }\end{array}$} & \multirow[b]{2}{*}{ dk } & \multirow{2}{*}{$\begin{array}{c}\text { Jumlah } \\
\text { Kuadrat } \\
\text { (JK) }\end{array}$} & \multirow{2}{*}{$\begin{array}{c}\text { Rata-rata } \\
\text { Jumlah } \\
\text { Kuadrat } \\
\text { (RJK) }\end{array}$} & \multirow[b]{2}{*}{$\mathbf{F}_{\text {hitung }}$} & \multicolumn{2}{|c|}{$\mathbf{F}_{\text {tabel }}$} \\
\hline & & & & & $\alpha=0,05$ & $\alpha=\mathbf{0 , 0 1}$ \\
\hline Total & 97 & 1718151 & & & & \\
\hline Regresi a & 1 & 1715301,04 & & & & \\
\hline Regresi b/a & 1 & 601,51 & 601,51 & $25,41 * *$ & 3,94 & 6,91 \\
\hline Residu & 95 & 2248,45 & 23,67 & & & \\
\hline $\begin{array}{l}\text { Tuna Cocok } \\
\text { Galat }\end{array}$ & $\begin{array}{l}21 \\
74\end{array}$ & $\begin{array}{c}433,87 \\
1814,58\end{array}$ & $\begin{array}{l}20,66 \\
24.52\end{array}$ & $0,84^{\mathrm{ns}}$ & 1,70 & 2,11 \\
\hline
\end{tabular}

\section{Keterangan :}

$\begin{array}{ll}* * & : \text { Regresi sangat signifikan }(25,41>6,91 \text { pada } \alpha=0,01) \\ \mathrm{ns} & : \text { Regresi berbentuk linear }(0,84<1,70 \text { pada } \alpha=0,05) \\ \mathrm{dk} & : \text { Derajat kebebasan } \\ \mathrm{JK} & : \text { Jumlah kuadrat } \\ \text { RJK } & : \text { Rata-rata jumlah kuadrat }\end{array}$

Persamaan regresi $\hat{X}_{3}=61,43+0,49 X_{2}$, untuk uji signifikansi diperoleh $F_{\text {hitung }} 25,41$ lebih besar dari pada $F_{\text {tabel }(0,01 ; 1: 95)} 6,91$ pada $\alpha=0,01$. Karena $F_{\text {hitung }}>F_{\text {tabel }}$ maka persamaan regresi dinyatakan sangat signifikan. Untuk uji linearitas diperoleh $\mathrm{F}_{\text {hitung }}$ sebesar 0,84 lebih kecil dari pada $F_{\text {tabel }(0,05 ; 21: 74)}$ sebesar 1,70 pada $\alpha=0,05$. Karena $F_{\text {hitung }}<F_{\text {tabel }}$ maka sebaran titik yang terestimasi membentuk garis linear dapat diterima. Secara visual dapat dilihat pada gambar 4.5.

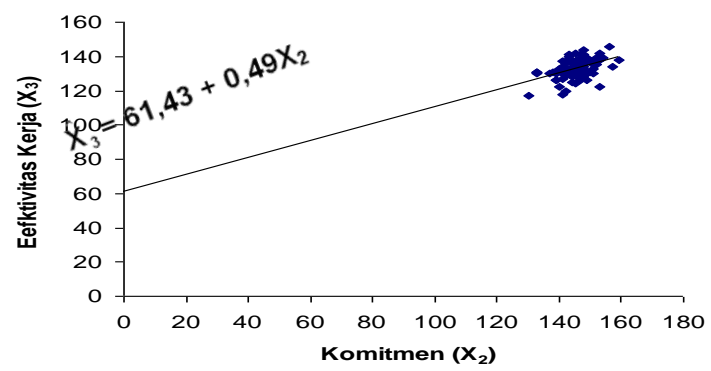

Gambar Grafik Persamaan Regresi $\hat{\mathbf{X}}_{3}=61,43+0,49 \mathrm{X}$

\section{Uji Signifikansi dan Linearitas Persamaan Regresi Komitmen atas Motivasi}

Dari data hasil perhitungan untuk penyusunan model persamaan regresi antara komitmen dengan motivasi pada lampiran 5 diperoleh konstanta regresi a $=100,73$ dan koefisien regresi $b=0,32$. Dengan demikian hubungan model persamaan regresi sederhana adalah $\hat{X}_{2}=100,73+0,32 X_{1}$. Sebelum model persamaan regresi tersebut dianalisis lebih lanjut dan digunakan dalam menarik kesimpulan, terlebih dahulu dilakukan uji signifikansi dan linearitas persamaan regresi. Hasil perhitungan uji signifikansi dan linearitas disusun pada tabel ANAVA seperti pada tabel di bawah ini: 
Tabel ANAVA Untuk Uji Signifikansi dan Linearitas Persamaan Regresi $\hat{X}_{2}=100,73+$

\begin{tabular}{|c|c|c|c|c|c|c|}
\hline \multicolumn{7}{|c|}{$0,32 X_{1}$} \\
\hline \multirow[b]{2}{*}{$\begin{array}{l}\text { Sumber } \\
\text { Varians }\end{array}$} & \multirow[b]{2}{*}{ dk } & \multirow{2}{*}{$\begin{array}{c}\text { Jumlah } \\
\text { Kuadrat } \\
\text { (JK) }\end{array}$} & \multirow{2}{*}{$\begin{array}{c}\text { Rata-rata } \\
\text { Jumlah } \\
\text { Kuadrat } \\
\text { (RJK) }\end{array}$} & \multirow[b]{2}{*}{$\mathbf{F}_{\text {hitung }}$} & \multicolumn{2}{|c|}{$\mathbf{F}_{\text {tabel }}$} \\
\hline & & & & & $\alpha=\mathbf{0 , 0 5}$ & $\alpha=\mathbf{0 , 0 1}$ \\
\hline Total & 97 & 2050906 & & & & \\
\hline Regresi a & 1 & 2048424,91 & & & & \\
\hline Regresi b/a & 1 & 238,81 & 238,81 & $10,12 * *$ & 3,94 & 6,91 \\
\hline Residu & 95 & 2242,28 & 23,60 & & & \\
\hline Tuna Cocok & 20 & 544,71 & 27,24 & $1,20^{\mathrm{ns}}$ & 1,71 & 2,13 \\
\hline Galat & 75 & 1697,57 & 22,63 & & & \\
\hline
\end{tabular}

Keterangan :

ns

: Regresi sangat signifikan $(10,12>6,91$ pada $\alpha=0,01)$

: Regresi berbentuk linear $(1,20<1,71$ pada $\alpha=0,05)$

$\mathrm{dk} \quad$ : Derajat kebebasan

JK : Jumlah kuadrat

RJK : Rata-rata jumlah kuadrat

Persamaan regresi $\hat{X}_{2}=100,73+0,32 X_{1}$, untuk uji signifikansi diperoleh $F_{\text {hitung }} 10,12$ lebih besar dari pada $F_{\text {tabel }(0,01 ; 1: 95)} 6,91$ pada $\alpha=0,01$. Karena $F_{\text {hitung }}>F_{\text {tabel }}$ maka persamaan regresi dinyatakan sangat signifikan. Untuk uji linearitas diperoleh $F_{\text {hitung }}$ sebesar 1,20 lebih kecil dari pada $F_{\text {tabel }(0,05: 20: 75)}$ sebesar 1,71 pada $\alpha=0,05$. Karena $F_{\text {hitung }}<F_{\text {tabel }}$ maka sebaran titik yang terestimasi membentuk garis linear dapat diterima. Secara visual dapat dilihat pada gambar 4.6.

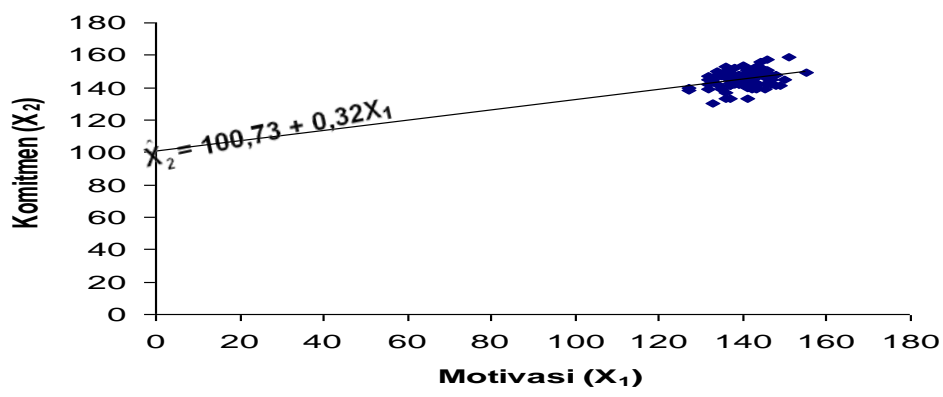

Gambar Grafik Persamaan Regresi $\hat{\mathbf{X}}_{\mathbf{2}}=100,73+0,32 \mathrm{X}$

Keseluruhan hasil uji signifikansi dan linearitas regresi dirangkum pada tabel berikut ini.

Tabel Hasil Uji Signifikansi dan Uji Linearitas Regresi

\begin{tabular}{|c|c|c|c|c|c|c|}
\hline \multirow[b]{2}{*}{ Reg } & \multirow[b]{2}{*}{ Persamaan } & \multicolumn{2}{|c|}{ Uji Regresi } & \multicolumn{2}{|c|}{ Uji Linearitas } & \multirow[b]{2}{*}{ Kesimpulan } \\
\hline & & $F_{\text {hitung }}$ & $\begin{array}{c}F_{\text {tabel }} \\
\alpha=0,01\end{array}$ & $\mathrm{~F}_{\text {hitung }}$ & $\begin{array}{c}F_{\text {tabel }} \\
\alpha=0,05\end{array}$ & \\
\hline $\begin{array}{l}X_{3} \\
\text { atas } \\
X_{1}\end{array}$ & $\hat{X}_{3}=63,01+0,50 X_{1}$ & $24,70 * *$ & 6,91 & $0,69^{\mathrm{ns}}$ & 1,71 & $\begin{array}{l}\text { Regresi sangat } \\
\text { signifikan/ } \\
\text { Regresi linear }\end{array}$ \\
\hline $\begin{array}{l}X_{3} \\
\text { atas } \\
X_{2} \\
\end{array}$ & $\hat{X}_{3}=61,43+0,49 X_{2}$ & $25,41 * *$ & 6,91 & $0,84^{\mathrm{ns}}$ & 1,70 & $\begin{array}{l}\text { Regresi sangat } \\
\text { signifikan/ } \\
\text { Regresi linear }\end{array}$ \\
\hline $\begin{array}{l}X_{2} \\
\text { atas } \\
X_{1} \\
\end{array}$ & $\hat{X}_{2}=100,73+0,32 X_{1}$ & $10,12 * *$ & 6,91 & $1,20^{\mathrm{ns}}$ & 1,71 & $\begin{array}{l}\text { Regresi sangat } \\
\text { signifikan/ } \\
\text { Regresi linear }\end{array}$ \\
\hline
\end{tabular}


Keterangan :

** : Sangat signifikan

ns $\quad$ : Non signifikan (regresi linear)

Dari hasil analisis pada bagian terdahulu dan proses perhitungan yang dilakukan dapat dirangkum sebagai berikut:

Tabel Matriks Koefisien Korelasi Sederhana antar Variabel

\begin{tabular}{|c|c|c|c|}
\hline \multirow{2}{*}{ Matrik } & \multicolumn{3}{|c|}{ Koefisien Korelasi } \\
\cline { 2 - 4 } & $\mathbf{X}_{\mathbf{1}}$ & $\mathbf{X}_{\mathbf{2}}$ & $\mathbf{X}_{\mathbf{3}}$ \\
\hline $\mathbf{X}_{\mathbf{1}}$ & 1,00 & 0,310 & 0,454 \\
\hline $\mathbf{X}_{\mathbf{2}}$ & & 1,00 & 0,459 \\
\hline $\mathbf{X}_{\mathbf{3}}$ & & & 1,00 \\
\hline
\end{tabular}

Dari tabel 4.9 dapat terlihat bahwa korelasi antara motivasi dengan komitmen sebesar 0,310. Korelasi antara motivasi dengan efektivitas kerja sebesar 0,454. Korelasi antara komitmen dengan efektivitas kerja sebesar 0,459.

\section{Pengaruh Motivasi terhadap Efektivitas Kerja}

Dari hasil pengujian hipotesis pertama dapat disimpulkan bahwa terdapat pengaruh langsung positif motivasi terhadap efektivitas kerja dengan nilai koefisien korelasi sebesar 0,454 dan nilai koefisien jalur sebesar 0,345. Ini memberikan makna motivasi berpengaruh langsung terhadap efektivitas kerja.

Hasil penelitian ini senada dengan pendapat beberapa ahli di antaranya adalah Jennifer M. George, Gereth R. Jones (2012:183), ${ }^{[24]}$ menyatakan bahwa, "when employees are motivated to contribute inputs at a high level (to work harder, more efficiently, and more creatively) and perform their jobs more effectively, organizational effectiveness increases." Pegawai termotivasi untuk bekerja lebih keras, lebih efisien, lebih kreatif, dan lebih efektif, agar meningkatkan efektivitas organisasi. Selanjutnya menurut Chuck Williams $(2009: 325),{ }^{[25]}$ menyatakan bahwa, "the primary goal of the model is to create jobs that result in positive personal and work outcomes such as internal work motivation, satisfaction with one's job, and work effectiveness". Maksud dari pernyataan tersebut yaitu tujuan utama dari model ini adalah motivasi internal bekerja untuk menciptakan lapangan kerja yang menghasilkan hasil pribadi dan kerja yang positif seperti kita, kepuasan dengan pekerjaan seseorang, dan efektivitas kerja. Adapun menurut McShane (2010:177), ${ }^{[26]}$ berpendapat bahwa, "employees who experience these psychological states tend to have higher levels of internal work motivation (motivation from the work itself), job satisfaction (particularly satisfaction with the work itself), and work effectiveness". Maksud dari pernyataan tersebut adalah Pegawai yang mengalami keadaan psikologis ini cenderung memiliki tingkat motivasi kerja internal (motivasi dari pekerjaan itu sendiri) yang lebih tinggi, kepuasan kerja (terutama kepuasan dengan pekerjaan itu sendiri), dan efektivitas kerja.

Motivasi berpengaruh langsung positif terhadap efektivitas kerja.

$\mathrm{H}_{0}: \beta_{31} \leq 0$

$\mathrm{H}_{1}: \beta_{31}>0$

$\mathrm{H}_{0}$ ditolak, jika $\mathrm{t}_{\text {hitung }}>\mathrm{t}_{\text {tabel }}$.

Dari hasil perhitungan analisis jalur, pengaruh langsung motivasi terhadap efektivitas kerja, nilai koefisien jalur sebesar 0,345 dan nilai koefisien $t_{\text {hitung }}$ sebesar 3,85. Nilai koefisien

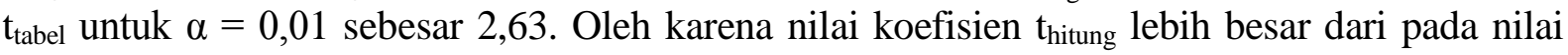


$\mathrm{t}_{\text {tabel }}$ maka dengan demikian $\mathrm{H}_{0}$ ditolak dan $\mathrm{H}_{1}$ diterima yaitu bahwa motivasi berpengaruh secara langsung terhadap efektivitas kerja dapat diterima.

Hasil analisis hipotesis pertama memberikan temuan bahwa motivasi berpengaruh secara langsung positif terhadap efektivitas kerja. Dengan demikian dapat disimpulkan bahwa efektivitas kerja dipengaruhi secara langsung positif oleh motivasi. Meningkatnya motivasi mengakibatkan peningkatan efektivitas kerja.

Tabel Koefisien Jalur Pengaruh $\mathbf{X}_{1}$ terhadap $\mathbf{X}_{3}$

\begin{tabular}{|c|c|c|c|c|}
\hline \multirow{2}{*}{ Pengaruh langsung } & \multirow{2}{*}{ Koefisien Jalur } & \multirow{2}{*}{$t_{\text {hitung }}$} & \multicolumn{2}{|c|}{$t_{\text {tabel }}$} \\
\hline & & & $\alpha=0,05$ & $\alpha=0,01$ \\
\hline $\mathrm{X}_{1}$ terhadap $\mathrm{X}_{3}$ & 0,345 & $3,85 * *$ & 1,99 & 2,63 \\
\hline
\end{tabular}

Koefisien jalur sangat signifikan

$(3,85>2,63$ pada $\alpha=0,01)$

\section{Pengaruh Komitmen terhadap Efektivitas Kerja}

Dari hasil pengujian hipotesis kedua dapat disimpukan bahwa terdapat pengaruh langsung positif komitmen terhadap efektivitas kerja dengan nilai koefisien korelasi sebesar 0,459 dan nilai koefisien jalur sebesar 0,352. Ini memberikan makna komitmen berpengaruh langsung terhadap efektivitas kerja.

Hasil penelitian ini senada dengan pendapat beberapa ahli di antaranya adalah Darcia Narvaez, dan Daniel K. Lapsley (2009:335), ${ }^{[27]}$ menyatakan bahwa, "the combination of commitment to moral principles, respect and concern for others, and lack of closedmindedness would usually seem to promote working effectively with others". Adapun maksud dari pernyataan tersebut adalah Kombinasi dari komitmen, moral, dan prinsip, serta rasa hormat dan kepedulian terhadap orang lain, biasanya akan meningkatkan efektivitas kerja dengan orang lain. Adapun menurut Gibson, dan Ivancevich (2006:184), ${ }^{[28]}$ menyatakan bahwa, "research evidence indicates that the absence of commitment can reduce organizational effectiveness". Bukti penelitian menunjukkan bahwa tidak adanya komitmen dapat mengurangi efektivitas organisasi. Selanjutnya menurut Edwin A. Locke (2009:356), ${ }^{[29]}$ mengemukakan bahwa, "commitment means the person is enthusiastic about the request and makes a maximum effort to do it effectivelly". Maksud dari pernyataan tersebut adalah komitmen merupakan ungkapan antusias orang usaha melakukan yang terbaik dan efektif dalam hal pekerjaan.

Komitmen berpengaruh langsung positif terhadap efektivitas kerja.

$\mathrm{H}_{0}: \beta_{32} \leq 0$

$\mathrm{H}_{1}: \beta_{32}>0$

$\mathrm{H}_{0}$ ditolak, jika $\mathrm{t}_{\text {hitung }}>\mathrm{t}_{\text {tabel }}$.

Dari hasil perhitungan analisis jalur, pengaruh langsung komitmen terhadap efektivitas kerja, nilai koefisien jalur sebesar 0,352 dan nilai koefisien $t_{\text {hitung }}$ sebesar 3,93. Nilai koefisien $\mathrm{t}_{\text {tabel }}$ untuk $\alpha=0,01$ sebesar 2,63. Oleh karena nilai koefisien $\mathrm{t}_{\text {hitung }}$ lebih besar dari pada nilai koefisien $\mathrm{t}_{\text {tabel }}$ maka $\mathrm{H}_{0}$ ditolak dan $\mathrm{H}_{1}$ diterima, dengan demikian komitmen berpengaruh secara langsung terhadap efektivitas kerja dapat diterima.

Hasil analisis hipotesis kedua menghasilkan temuan bahwa komitmen berpengaruh secara langsung positif terhadap efektivitas kerja. Berdasarkan hasil temuan tersebut dapat 
disimpulkan bahwa efektivitas kerja dipengaruhi secara langsung positif oleh komitmen. Meningkatnya komitmen mengakibatkan peningkatan efektivitas kerja.

\section{Tabel Koefisien Jalur Pengaruh $\mathbf{X}_{2}$ terhadap $\mathbf{X}_{3}$}

\begin{tabular}{|l|l|l|l|l|}
\hline \multirow{2}{*}{ Pengaruh langsung } & \multirow{2}{*}{ Koefisien Jalur } & \multirow{2}{*}{$\mathrm{t}_{\text {hitung }}$} & $\mathrm{t}_{\text {tabel }}$ & \\
\cline { 4 - 5 } & & $\alpha=0,05$ & $\alpha=0,01$ \\
\hline $\mathrm{X}_{2}$ terhadap $\mathrm{X}_{3}$ & 0,352 & $3,93 * *$ & 1,99 & 2,63 \\
\hline
\end{tabular}

** Koefisien jalur sangat signifikan $(3,93>2,63$ pada $\alpha=0,01)$

\section{Pengaruh Motivasi terhadap Komitmen}

Dari hasil pengujian hipotesis ketiga dapat disimpulkan bahwa terdapat pengaruh langsung positif motivasi terhadap komitmen dengan nilai koefisien korelasi sebesar 0,310 dan nilai koefisien jalur sebesar 0,310. Ini memberikan makna motivasi berpengaruh langsung terhadap komitmen.

Hasil penelitian ini senada dengan pendapat beberapa ahli di antaranya adalah menurut Marshall et al (2010:113), ${ }^{[30]}$ menyatakan bahwa, "where employees are commited to their organization and pride being a member of it, and they are fully enganged in their work because it fullfils their need to do work the matters, motivation, retention, discretionary effort, and financial outcomes are all very high." Esensi dari pendapat di atas, karyawan yang memiliki komitmen terhadap perusahaannya bangga menjadi anggota diperusahaan tersebut. Karyawan merasa memiliki keterlibatan yang kuat pada pekerjaannya yang disebabkan harapan-harapan mereka untuk memenuhi kebutuhan melalui motivasi, ingatan, upaya persatuan pilihan, dan penghasilan telah terpenuhi. Menurut David J. Cooper (2012:96), ${ }^{\text {[31] }}$ berpendapat bahwa, "makes a strong link between motivation and commitment by suggesting that most observers consider motivation to be concerned with an individual's expenditure of effort and energy and a sense of work commitment." Maksud dari pernyataan tersebut adalah ada hubungan yang kuat antara motivasi dan komitmen dengan menyarankan bahwa sebagian besar pengamat menganggap motivasi merupakan usaha yang dilakukan individu dengan energi yang kuat sehingga dapat menimbulkan rasa kepedulian dalam komitmen kerja. Selanjutnya menurut Derek Torrington (2010:231), ${ }^{[32]}$ mengemukakan bahwa, "motivation and incentive (in that people can be motivated to use their ability productively via intrinsic and extrinsic rewards) and opportunity. In turn these three factors have an impact on commitment, individual motivation and job satisfaction, all of which have an impact on employee discretionary behaviour which in turn impacts on performance." Adapun maksud dari pendapat di atas motivasi dan insentif (bahwa orang dapat termotivasi untuk menggunakan kemampuan mereka secara produktif melalui imbalan intrinsik dan ekstrinsik) dan peluang. Pada gilirannya ketiga faktor ini berdampak pada komitmen, motivasi individu dan kepuasan kerja, yang semuanya berdampak pada perilaku karyawan diskresioner yang pada gilirannya berdampak pada kinerja. Menurut Achua Lussier (2013:77), [33] mengemukakan, "success is about motivation that includes effort, commitment, being engaged, practice, and persistence". Maksud dari pernyataan tersebut adalah keberhasilan merupakan bagian dari motivasi yang meliputi usaha, keterlibatan komitmen, praktek, dan gigih. Menurut pendapat Colquitt (2015:189), ${ }^{[34]}$ menyatakan bahwa, "less is known the effect of motivation on organizational commitment. however, equity has a moderate positive effect. People who experience higher levels or equity tend to feel higher levels of affective commitment and higher level of normative commitment effects on continuance commitment are weaker." Dari pendapat di atas dapat diartikan bahwa sedikit yang diketahui pengaruh motivasi terhadap komitmen organisasi. Namun, ekuitas memiliki efek positif moderat. 
orang-orang yang mengalami tingkat yang lebih tinggi atau ekuitas cenderung merasa tingkat yang lebih tinggi komitmen afektif dan tingkat yang lebih tinggi dari efek komitmen normatif pada komitmen kontinyu lebih lemah.

Motivasi berpengaruh langsung positif terhadap komitmen.

$\mathrm{H}_{0}: \beta_{21} \leq 0$

$\mathrm{H}_{1}: \beta_{21}>0$

$\mathrm{H}_{0}$ ditolak, jika $\mathrm{t}_{\text {hitung }}>\mathrm{t}_{\text {tabel }}$.

Dari hasil perhitungan analisis jalur, pengaruh langsung motivasi terhadap komitmen, nilai koefisien jalur sebesar 0,310 dan nilai koefisien $t_{\text {hitung }}$ sebesar 3,18. Nilai koefisien $t_{\text {tabel }}$ untuk $\alpha=0,01$ sebesar 2,63. Oleh karena nilai koefisien $t_{\text {hitung }}$ lebih besar dari pada nilai $t_{\text {tabel }}$ maka dengan demikian $\mathrm{H}_{0}$ ditolak dan $\mathrm{H}_{1}$ diterima yaitu bahwa motivasi berpengaruh secara langsung terhadap komitmen dapat diterima.

Hasil analisis hipotesis ketiga memberikan temuan bahwa motivasi berpengaruh secara langsung positif terhadap komitmen. Dengan demikian dapat disimpulkan bahwa komitmen dipengaruhi secara langsung positif oleh motivasi. Meningkatnya motivasi mengakibatkan peningkatan komitmen.

Tabel Koefisien Jalur Pengaruh $\mathbf{X}_{1}$ terhadap $\mathbf{X}_{2}$

\begin{tabular}{|l|l|l|l|l|}
\hline \multirow{2}{*}{ Pengaruh langsung } & \multirow{2}{*}{ Koefisien Jalur } & \multirow{2}{*}{$\mathrm{t}_{\text {hitung }}$} & \multicolumn{2}{|l|}{$\mathrm{t}_{\text {tabel }}$} \\
\cline { 4 - 5 } & & $\alpha=0,05$ & $\alpha=0,01$ \\
\hline $\mathrm{X}_{1}$ terhadap $\mathrm{X}_{2}$ & 0,310 & $3,18 * *$ & 1,99 & 2,63 \\
\hline
\end{tabular}

** Koefisien jalur sangat signifikan $(3,18>2,63$ pada $\alpha=0,01)$

Rangkuman hasil pengujian hipotesis dapat terlihat pada tabel berikut ini:

Tabel Rangkuman Hasil Pengujian Hipotesis yang Diajukan

\begin{tabular}{|l|l|l|l|}
\hline \multicolumn{1}{|c|}{ Hipotesis } & \multicolumn{1}{|c|}{$\begin{array}{c}\text { Hipotesis } \\
\text { Statistik }\end{array}$} & \multicolumn{1}{c|}{ Keputusan } & Kesimpulan \\
\hline $\begin{array}{l}\text { Motivasi berpengaruh langsung } \\
\text { positif terhadap efektivitas kerja }\end{array}$ & $\begin{array}{l}\mathrm{H}_{0}: \beta_{31} \leq 0 \\
\mathrm{H}_{1}: \beta_{31}>0\end{array}$ & $\mathrm{H}_{0}$ ditolak & $\begin{array}{l}\text { Berpengaruh } \\
\text { langsung } \\
\text { positif }\end{array}$ \\
\hline $\begin{array}{l}\text { Komitmen berpengaruh langsung } \\
\text { positif terhadap efektivitas kerja }\end{array}$ & $\begin{array}{l}\mathrm{H}_{0}: \beta_{32} \leq 0 \\
\mathrm{H}_{1}: \beta_{32}>0\end{array}$ & $\mathrm{H}_{0}$ ditolak & $\begin{array}{l}\text { Berpengaruh } \\
\text { langsung } \\
\text { positif }\end{array}$ \\
\hline $\begin{array}{l}\text { Motivasi berpengaruh langsung } \\
\text { positif terhadap komitmen }\end{array}$ & $\begin{array}{l}\mathrm{H}_{0}: \beta_{21} \leq 0 \\
\mathrm{H}_{1}: \beta_{21}>0\end{array}$ & $\mathrm{H}_{0}$ ditolak & $\begin{array}{l}\text { Berpengaruh } \\
\text { langsung } \\
\text { positif }\end{array}$ \\
\hline
\end{tabular}

Ringkasan model analisis jalur dapat terlihat pada gambar sebagai berikut: 


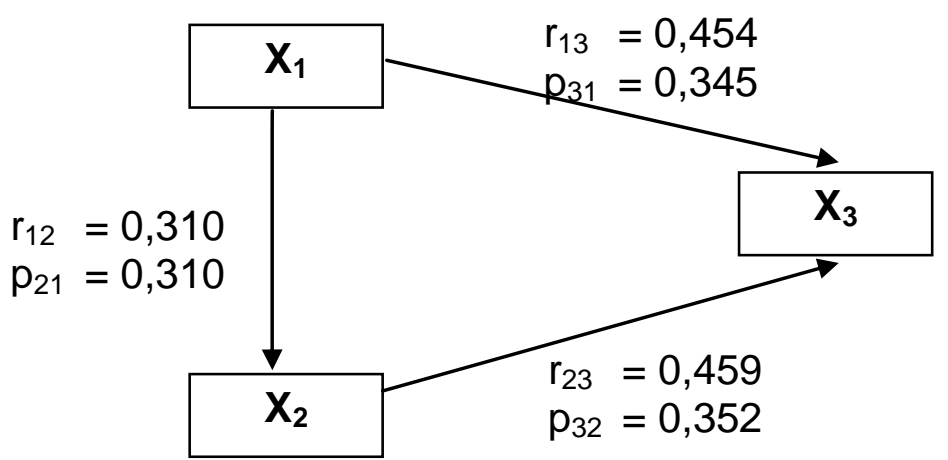

Gambar Model Empiris Antar Variabel

\section{KESIMPULAN DAN SARAN}

\section{Kesimpulan}

Berdasarkan hasil pengujian hipotesis, pembahasan hasil data penelitian dan hasil analisis data penelitian yang dibahas pada bab IV dengan semua persyaratan analisis data yang meliputi, uji linieritas serta keberartian regresi telah dipenuhi, maka dapat diambil beberapa kesimpulan sebagai berikut: I. Kesimpulan Terhadap Rumusan Masalah, a). Motivasi berpengaruh langsung positif terhadap efektivitas kerja, hal ini menunjukkan bahwa motivasi yang tinggi akan meningkatkan efektivitas kerja, semakin tinggi motivasi maka akan semakin baik efektivitas kerja guru SD Negeri Kecamatan Cabangbungin Kabupaten Bekasi. b). Komitmen berpengaruh langsung positif terhadap efektivitas kerja, hal ini menunjukkan bahwa komitmen yang tinggi akan meningkatkan efektivitas kerja, semakin tinggi komitmen maka akan semakin baik efektivitas kerja guru SD Negeri Kecamatan Cabangbungin Kabupaten Bekasi. Dari hasil penelitian didapatkan bahwa variabel yang paling berpengaruh adalah komitmen terhadap efektivitas kerja, hal ini dapat dibuktikan dari hasil perhitungan statistik dengan nilai $\mathrm{r}_{23} \quad=0,459, \mathrm{p}_{32}=0,352$ paling tinggi dibandingkan pengaruh antar variabel lainnya. c). Motivasi berpengaruh langsung positif terhadap komitmen, hal ini menunjukkan bahwa motivasi yang tinggi akan meningkatkan komitmen, pengakuan atas kerja guru dan pemberian apresiasi atas hasil kerja guru. II. Kesimpulan Terhadap Tujuan Penelitian, a). Guru diharapkan memahami apa itu motivasi, serta meningkatkan komitmen dalam bekerja, dan menciptakan efektivitas kerja. Kepala Sekolah pada SD Negeri Kecamatan Cabangbungin, diharapkan membantu para guru agar memiliki motivasi tinggi dalam bekerja, meningkatkan komitmen, serta menciptakan efektivitas kerja. b). Dinas Pendidikan Kabupaten Bekasi, berperan dalam upaya pembinaan guru, c). Bagi peneliti, berguna dalam menambah ilmu pengetahuan khususnya tentang penelitian pada suatu permasalahan tertentu yaitu pengetahuan efektivitas kerja guru.

\section{Saran}

Berdasarkan kesimpulan dan implikasi di atas, beberapa saran yang dapat disampaikan peneliti adalah sebagai berikut: (1) Dengan komitmen yang tinggi dari dalam diri guru maka akan menjaga suasana kondusif di tempat kerja, semangat dalam beraktivitas, akrab dengan rekan kerja, melaksanakan tugas dengan baik, siap menerima kritik dan saran dari teman sejawat/guru, kepala sekolah, siswa-siswa, dan staf sekolah yang lain. pelayanan yang maksimal kepada siswa, tanggung jawab mengajar dan melaporkan hasil kegiatan kepada atasan, tegas dalam bersikap, serta tidak membeda-bedakan. (2) Peningkatan motivasi perlu dilakukan karena dengan motivasi tinggi dapat diketahui sejauh mana guru memiliki 
semangat kerja. Guru PNS ataupun Honorer sudah selayaknya bekerja dengan giat, setulus hati, penuh dedikasi, tidak hanya mengaharapkan gaji yang besar saja tanpa di barengi dengan efektivitas kerjanya yang baik. (3) Efektivitas kerja yang optimal dapat dicapai karena adanya dukungan dari organisasi atau sekolah tempat bekerja. Sekolah yang kondusif lingkungan internal sekolah dapat menunjang kualitas pekerjaan. Oleh karena itu tidak ada kata lain selain guru harus meningkatkan motivasi dan memiliki komitmen yang tinggi dalam berupaya mendapatkan efektivitas kerjanya secara optimal.

\section{DAFTAR PUSTAKA}

[1] http://www.mediasorot.com/?p=1378. (diakses pada 20 November 2014).

[2] Jones, Gareth R., Jennifer M. George. 2012. Contemporary Management. New York: McGraw-Hill.

[3] Wagner, and Hollenbeck. 2010. Organizational Behavior. Securiting Competitive Advantage. New York: Routledge.

[4] Robbins, Stephen P., Mary Coulter. 2012. Management. New Jersey: Prentice Hall.

[5] Mullins, Laurie J. 2010. Management and Organisational Behavior. London: Prentice Hall.

[6] Sims, Ronald R. 2011. Managing Organizational Behavior. London: Westport Connecticut.

[7] Sperry, Len. 2011. Effective Leadership, Executive, Productivity and Health. London: Psychology Press.

[8] Minner John B. 2010. Organizational Behavior, Essential theories of Motivation and Leadership. New York: M.E. Sharpe,.

[9] Werther William B., Jr. And Keith Davis, 2013. Human Resources and Personnel Management. Boston: Mc. Graw-Hills, International Edition.

[10] Champoux Joseph. E., 2011. Organizational Behavior: Integrating Individuals, Groups and Organizations. New York: West Publishing Company.

[11] Gibson, James L., James H Donelly. 2012. Organizations Behavior, Structure, Processes.New York: McGraw-Hill.

[12] Schermerhorn, Osborn, Uhl-Bein, dan Hunt. 2012. Organizational Behavior USA: John Willey \& Sons (Asia) Pte Ltd.

[13] McShane, Von Glinow, 2010. Organizational Behavior. New York: McGraw-Hill.

[14] Colquitt, LePine, Wesson. 2015. Organizational Behavior. New York: McGraw-Hill.

[15] Robbins, Stephen P., Mary Coulter. 2012. Management. New Jersey: Prentice Hall.

[16] Deporter, Bobbi dan Mike Hinaki. 2010. Quantum Bisnis, membiasakan Berbisnis Secara Etis dan Sehat. Bandung: Kaifa.

[17] Gibson, James L., James H Donelly. 2012. Organizations Behavior, Structure, Processes. New York: McGraw-Hill.

[18] Kail, Robert V., John C. 2013. Cavanaugh. Human Development A Life-Span View. USA: Wadsworth. Cengage.

[19] Yukl, Gary. 2010. Leadership In Organizations. New Jersey: Pearson Education, Inc., Upper Saddle River.

[20] Hellriegel, Don. Slocum, John W. 2011. Organizational Behavior Thirteenth Edition. South Western: Mason.

[21] Howle Donna, R.N., B.S.N., The Relationship Between The Work Effectiveness Of Staff Nurses And Their Preception Of Their Nurse Managers' Empowerment: ProQuest Information and Learning 300 North Zeeb Road, Ann Arbor, Ml 48106-1346 USA 800521-0600, Copyright 2001 by Bell \& Howell Information and Learning Company. (diakses pada 22 Januari 2015). 
[22] Kanchanopast Supattra, Working Motivation Factors Affecting Job Performance Effectiveness, Vol:7 No:8, 2013. 1175. http://waset.org/publications/16244/workingmotivation-factors-affecting-job-performance-effectiveness. (diakses pada 25 Januari 2015).

[23] Mary E. Guy, Seung-Bum Yang, “The Effectiveness of Self-Managed Work Teams in Government Organizations", Published online: 25 December 2010, Springer Science Business Media, LLC 2010. http://media.proquest.com. (diakses pada 3 Juli 2015).

[24] George, Jennifer M. Gareth R. Jones. 2012. Understanding and Managing Organizational Behavior. Sixth Edition. New Jersey: Upper Saddle River.

[25] Williams Chuck. 2009. Management. Canada: Cengage Learning.

[26] McShane, Von Glinow. 2010. Organizational Behavior. New York: McGraw-Hill.

[27] Narvaez, Darcia and Daniel K. Lapsley. 2009. Personality Identity, and Character, Explorations in Moral Psychology. New York: Cambridge.

[28] Gibson, Ivancevich. 2012. Organizations Behavior, Structure, Processes. New York: McGraw-Hill.

[29] Locke Edwin A. 2009. Hanbook of Principles of Organizational Behavior. United Kingdom: John Wiley \& Sons Ltd.

[30] Goldsmith, Marshall, John Baldoni, Sarah Mc Arthur. 2010. The AMA Handbook of leadership. New York: AMACOM.

[31] Cooper David J. 2012. Leadership For Follower Commitment. United Kingdom: Butterworth-Heinemann.

[32] Torrington Derek, Laura Hall, and Stephen Taylor. 2010. Human Resource Management. United Kingdom: Prentice Hall.

[33] Lussier Achua. 2013. Effective Leadership. Canada: Cengage Learning.

[34] Colquitt, LePine, Wesson. 2015. Organizational Behavior. New York: McGraw-Hill. 